\title{
Assessment of Radioactivity in Various Types of Soil From Al-Obour City, Egypt.
}

A. Nada, F. M. Ragab*, Hosnia M. Abu-Zied, M. Mostafa

Physics Department, Faculty of Women for Art, Science and Education, Ain Shams University, Cairo, Egypt.

Fatma.ragab@woman.asu.edu.eg

\begin{abstract}
The distributions of natural radioactivity in various types of samples collected from several areas in Al-Obour city were determined using a high purity germanium (HPGe) detector. Four types of samples were investigated: soil, foundations, sand dunes and rock samples. The specific activities of 238U, 226Ra series, 232Th and 40K in soil; foundations; sand dunes and rock samples have a mean of $(13.31 \pm 3.59) ;(12.96 \pm 3.63)$; (13.36 \pm 4.32$)$ and $(26.74 \pm 5.50),(6.49 \pm 0.23) ;(3.71 \pm 0.16) ;(3.87 \pm 0.17)$ and $(19.38 \pm 0.64),(6.52 \pm 0.55) ;(4.03 \pm 0.46)$; $(3.90 \pm 0.45)$ and $(25.91 \pm 1.89)$ and $(96.21 \pm 1.60) ;(78.12 \pm 1.46) ;(76.27 \pm 1.43)$ and $(215.71 \pm 3.35) \mathrm{Bq} / \mathrm{kg}$, respectively.It was also noticed that $137 \mathrm{Cs}$ is existed in some samples but is close to the background level. The hazard indices were also determined in all types of samples of the under study area. These values are important to establish baseline levels of this environmental radioactivity to detect any upcoming change for the local population.
\end{abstract}

.Indexing terms/Keywords Gamma-spectroscopy, Heavy metals, Natural radioactivity, hazard indices

Language: English

Date of Publication: 31-05-2018

DOI: $10.24297 / j a p . v 14 i 2.7370$

ISSN: 2347-3487

Volume: 14 Issue: 2

Journal: Journal of Advances in Physics

Website: https://cirworld.com

This work is licensed under a Creative Commons Attribution 4.0 International License. 


\section{Introduction}

The radionuclides are not uniformly distributed in soils and environmental radioactivity, and the associated external gamma exposure, depends strongly on geological and geographical conditions. The specific levels of terrestrial environmental radiation of a territory are usually related to its lithological composition and to the concentrations of thorium (Th), uranium $(U)$ andpotassium $(K)$ of the rock from which the soils originated [1]. The natural terrestrial gamma dose rate is an important contributor to the average dose received by world's population [2]. The measurement of natural radioactivity due to gamma rays from the dose rate is needed to implement precautionary measures whenever the dose is found to be above the recommended limits [3].The prime objective of this investigation is to determine natural (238U, 232Th, 40K) and artificial (137Cs) radioactivity levels in soil, foundations, sand dunes and rock samples collected from the area under study. Also, the radiation hazard indices have been estimated and compared with the recommended limits. The results of this study will provide background data on natural and artificial radioactive isotopes and environmental pollution.

\section{Materials and Methods}

\subsection{Location of the study area:}

Al-Obour city is a newly constructed city located at $25 \mathrm{~km}$ of Cairo. The city covers almost $210 \mathrm{~km} 2$, and is characterized by significant variations in topography and geology [4]. It is bounded by Cairo-Ismailia high way

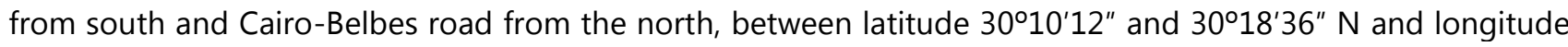
$31^{\circ} 26^{\prime} 00^{\prime \prime}$ and 31031'12" E shown in [Fig.1].
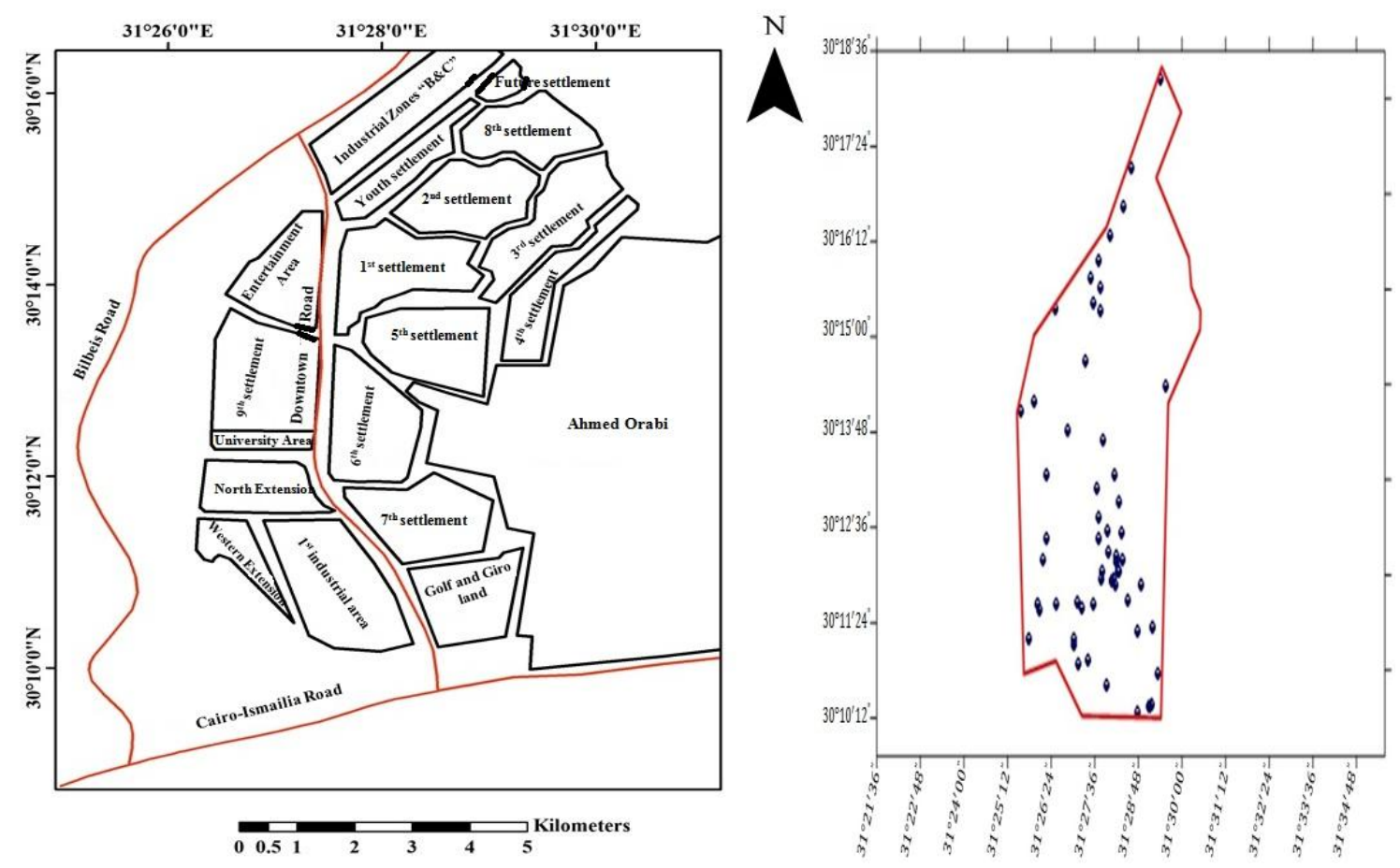

Fig.1: Map and locations of samples collected from Al-Obour city.

\subsection{Geology of Al-Obour city:}

The study area has a relatively low relief, except its northern part that comprises more rugged relief. The low relief area includes three geomorphic landforms: sand dunes, plains and wadies. On the other hand, the rugged area comprises other two geomorphic landforms: structural high-table lands and flat topped hills. The sand dunes cover about $10 \%$ of the study area. Their presence is restricted in two fields. The first occupies the western border of the area and is known as G. El-Asfar dune belt while the second occupies a strip located just 
north Cairo-Ismailia highway, in addition to a few locations within Al-Obour city. The sand dunes in the study area are of two types which are sief and barchan dunes. Plains cover about $72.5 \%$ of the study area. They occupy the extreme north of the study area. The southern plains are covered with thick deposits of Nonmarine Miocene while the northern ones are occupied mainly by the Nonmarine Miocene and, in places, by the Oligocene sands. Both types of plains have streaks of Quaternary sand filling the dry wadi streams. Wadies cover about $1.25 \%$ of the study area. They present the channel paths of old stream which were running through the area in the past or during the present temporary rainfall episodes. The high topographic lands represented by flat topped hills are occupying a few locations to the south and southeast of the northern part of El-Obour City. These hills are capped by the dolomite beds of the Miocene rock Subnit (M2) forming the northern and western dip slope sides, while the claystone and sandstones form the eastern and southern steep wall sides of these hills[5].

\subsection{Samples description and preparation technique:}

19 soil samples were collected from the first industrial area and industrial zones "B\&C" of Al-Obour city. The samples were sandy silt, clayey sand, silty sand, grayish white, friable to soft, calcareous in parts and rich in plant debris. 21 foundations samples were collected from the 6th, 7th, 9th settlements and the entertainment area. They were sand, medium to fine, friable, loose, yellowish white and clayey in parts. Also, 25 sand dunes samples were collected from the northern, western extensions and the golf and Giro land area. They were sief and barchan dunes samples. Finally, 17 rock samples were collected from two sections located in the 4th and 5th settlements and they were mainly claystone and sandstone rocks.A Global Positioning System (GPS) was used to determine geographical coordinates shown in Fig.1.

The samples were dried, pulverised, homogenized, weighed and sieved to pass through $2 \mathrm{~mm}$ mesh size and the meshed soil samples were transferred to Marinelli beakers having volumes of 250 and $100 \mathrm{ml}$ and sealed for a period of about four weeks before counting by gamma spectrometry in order to allow 226Ra and its short-lived progenies to reach secular radioactive equilibrium and to ensure that radon gas is confined within the volume and the daughters also remain in the sample [6].

\subsection{Analytical techniques:}

The activity concentrations of $238 \mathrm{U}, 232 \mathrm{Th}, 40 \mathrm{~K}$ and $137 \mathrm{Cs}$ in the samples were measured for all samples using a high purity germanium (HPGe) detector, model (GEM-50210-P), a P-type crystal, from EG\&G ORTEC. It has a resolution (FWHM) of $1.9 \mathrm{keV}$ for the $1332 \mathrm{keV}$ gamma- ray line of $60 \mathrm{Co}$ and a relative efficiency of about $50 \%$.The efficiency calibration was performed by using three well-known reference materials obtained from the International Atomic Energy Agency for $U$, Th and K activity measurements: RGU-1, RGTh-1 and RGK$1[7,8]$. Absolute efficiency calibration of the gamma spectrometry system was carried out using the radionuclide specific efficiency method in order to reduce the uncertainty in gamma-ray intensities, as well as the influence of coincidence summation and self-absorption effects of the emitting gamma photons [9].The gamma-ray transitions of 228Ac $(338.4,911 \mathrm{keV}), 212 \mathrm{Bi}(727.3,1620.7 \mathrm{keV})$ and $208 \mathrm{TI}(583.1,2614.4 \mathrm{keV})$ were used to evaluate the specific activities of Th-series radionuclides. The activity concentrations of $238 \mathrm{U}$ were measured from gamma-ray transition of $234 \mathrm{mPa}(1001 \mathrm{keV})$ while $226 \mathrm{Ra}$ was determined from (186.1 keV), $214 \mathrm{~Pb}$ from $(351.1,295.1 \mathrm{keV})$ and $(609.3,1120.3,1764.5 \mathrm{keV})$ for $214 \mathrm{Bi}$. 40K was determined from the $1460 \mathrm{keV}$ photo peak and the activity concentration of $137 \mathrm{Cs}$ was determined from $661.66 \mathrm{keV}$ gamma-ray transition [10].

For soil samples, the soil solution was analyzed for the determination of heavy metals using the Inductively Coupled Plasma-Optical (ICP-OES) with ultrasonic nebulizer (USN), this nebulizer decrease the instrumental detection limits, which is Perkin Elmer Optima 3000, USA which is existed in the Desert Research Center in Cairo, Egypt. 


\subsection{Radioactivity counting:}

The samples were counted for a counting time of about $24 \mathrm{~h}$. The net area count after background corrections in each photo peak was used in the computation of the activity concentration C (Bqkg-1) for each of the radionuclides in the samples using the expression [11]:

$$
\mathrm{C}(\mathrm{Bq} / \mathbf{k g})=\frac{\mathrm{C}_{\mathrm{n}}}{\varepsilon \mathbf{P}_{\gamma} \mathbf{M}_{\mathrm{s}}}
$$

where $\mathrm{C}_{\mathrm{n}}$ is the count rate under each photo peak due to each radionuclide, $\varepsilon$ is the detector efficiency for the specific $\gamma$-ray, $P_{\gamma}$ is the absolute transition probability of the specific $\gamma$-ray and $M_{s}$ is the mass of the sample $(\mathrm{kg})$. The LLD values obtained were 9.347, 1.310, 1.344 and $0.025 \mathrm{Bqkg}-1$ for $40 \mathrm{~K}, 238 \mathrm{U}, 232 \mathrm{Th}$ and $137 \mathrm{Cs}$, respectively.

\subsection{Hazard indices:}

The activity concentrations of $40 \mathrm{~K}, 238 \mathrm{U}$ and $232 \mathrm{Th}$ measured in each of the studied samples indicate the quantity of radioactivity present but do not provide a measure of radiation risks in the form of an absorbed dose rate. The absorbed dose rate, $\mathrm{D}(\mathrm{nGyh}-1)$ in air at $1 \mathrm{~m}$ above ground level due to the presence of $238 \mathrm{U}$, 232Th and 40K in the studied samples at each studied site was calculated using the following equation [12]:

$$
\mathrm{D}=\mathbf{a C}_{\mathrm{U}}+\mathbf{b C}_{\mathrm{Th}}+\mathbf{c C}_{\mathrm{K}}+\mathbf{d C}_{\mathrm{Cs}}
$$

where $\mathrm{a}$ is the dose rate per unit $238 \mathrm{U}$ activity concentration $\left(4.27 \times 10^{-10} \mathrm{Gyh}^{-1} / \mathrm{Bqkg}^{-1}\right), \mathrm{C}_{\mathrm{U}}$ is the concentration of $238 \mathrm{U}$ in the sample $(\mathrm{Bqkg}-1), \mathrm{b}$ is the dose rate per unit 232Th activity concentration $\left(6.62 \times 10^{-10} \mathrm{Gyh}^{-1} / \mathrm{Bqkg}^{-1}\right), \mathrm{C}_{\mathrm{Th}}$ is the concentration of $232 \mathrm{Th}$ in the sample $(\mathrm{Bqkg}-1), \mathrm{c}$ is the dose rate per unit $40 \mathrm{~K}$ activity concentration $\left(0.43 \times 10^{-10} \mathrm{Gyh}^{-1} / \mathrm{Bqkg}^{-1}\right), \mathrm{C}_{\mathrm{K}}$ is the concentration of $40 \mathrm{~K}(\mathrm{Bqkg}-1), \mathrm{d}$ is the dose rate per unit $137 \mathrm{Cs}$ activity concentration $\left(0.30 \times 10^{-10} \mathrm{Gyh}^{-1} / \mathrm{Bqkg}^{-1}\right), \mathrm{C}_{\mathrm{Cs}}$ is the concentration of $137 \mathrm{Cs}$ in the sample (Bqkg-1) $[13,11]$.

To estimate the annual effective dose rates, the conversion coefficient from absorbed dose in air to effective dose (0.7) and outdoor occupancy factor (0.2) proposed by UNSCEAR (2000) were used. The effective dose rate in units of $\mathrm{mSv}$ per year was determined using the following formula:

$$
\text { Out door annual effective dose }=D_{\text {air }} \times 8760 \mathrm{~h} \times 0.7 \mathrm{SvGy}^{-1} \times 0.2 \times 10^{-6}
$$

The radium equivalent activity is a weighted sum of activities of $226 \mathrm{Ra}, 232 \mathrm{Th}$ and $40 \mathrm{~K}$ based on the presumption that $10 \mathrm{Bqkg}-1$ of $226 \mathrm{Ra}, 7 \mathrm{Bqkg}-1$ of $232 \mathrm{Th}$ or $130 \mathrm{Bqkg}-1$ of $40 \mathrm{~K}$ produce the same gamma-ray dose rates. Hence it is defined as follows:

$$
R a_{\text {eq }}=A_{\text {Ra }}+1.43 A_{\text {Th }}+0.077 A_{K}
$$

where $A_{R a}, A_{T h}$ and $A_{K}$ are activities of $226 R a, 232 T h$ and $40 K$, respectively, in Bqkg-1. The maximum value of $\mathrm{Ra}_{\text {eq }}$ must be $<370$ Bqkg-1[14] in order to keep the external dose $<1.5 \mathrm{mGy} / \mathrm{y}$.

A modified quantity of radium equivalent activity is the external hazard index $\mathrm{H}_{\mathrm{ex}}$, which is defined as follows:

$$
\mathbf{H}_{\text {ex }}=\frac{\mathbf{A}_{\mathrm{Ra}}}{370}+\frac{\mathbf{A}_{\mathrm{Th}}}{\mathbf{2 5 9}}+\frac{\mathbf{A}_{\mathrm{K}}}{\mathbf{4 8 1 0}}
$$

The value of $\mathrm{H}_{\mathrm{ex}}$ must be lower than unity in order to keep the radiation hazard in significant. The maximum value of unity for $\mathrm{H}_{\mathrm{ex}}$ corresponds to the limit of $370 \mathrm{Bqkg}-1$ forRa $\mathrm{eq}[15]$. 
The annual gonadal dose equivalent (AGED) is the genetic relevance of the dose equivalent received each year by the reproductive organs of the exposed population can be calculated according thefollowing equation [16]

$$
\operatorname{AGDE}(\mu \mathrm{Sv} / \mathrm{y})=3.09 \mathrm{CRa}+4.18 \mathrm{CTh}+0.314 \mathrm{CK}
$$

The activity utilization index is the dose rate in air from different combinations of the three original radionuclides present in soil samples are expressed by the activity utilization index, AUI. AUI is calculated by applying the appropriate conversion factors, along with the radioactivity concentrations of the three respective radionuclides from the following equation [17]

$$
\text { AUI }=\frac{c_{\text {Ra }}}{50^{\mathrm{Bq}} / \mathrm{kg}} \mathbf{f}_{\mathrm{Ra}}+\frac{\mathrm{c}_{\mathrm{Th}}}{50^{\mathrm{Bq}} / \mathrm{kg}} \mathbf{f}_{\mathrm{Th}}+\frac{\mathrm{c}_{\mathrm{k}}}{500^{\mathrm{Bq}} / \mathrm{kg}} \mathbf{f}_{\mathrm{k}}
$$

Where CRa , CTh and CK are the concentration of 226Ra, 232Th and 40K in BqKg-1 respectively. fRa, fTh and $\mathrm{fK}$ are the respective fractional contributions from the actual activities of radionuclides $226 \mathrm{Ra}$, 232Th and $40 \mathrm{~K}$ which equal $0.462,0.0604$ and 0.041 respectively.

Consequent according the evaluation of annual effective dose equivalent (AEDE) the excess lifetime cancer risk factor (ELCR) was estimated using equation [17]

$$
E L C R=A E D \times D L \times R F
$$

where: $\mathrm{DL}$ and $\mathrm{RF}$ are the duration of life (70 year) and risk factor $0.05 \mathrm{~Sv}^{-1}$

\section{Results and Discussion}

The specific activity concentrations for 238U, 226Ra series, 232Th series and 40K in the samples are shown in Table 1.

\begin{tabular}{|c|c|c|c|c|c|c|}
\hline Type & Location & $\begin{array}{c}\text { No. of } \\
\text { samples }\end{array}$ & $238 U$ & 226Ra & 232Th & $40 \mathrm{~K}$ \\
\hline Soil & $\begin{array}{c}\text { First industrial area } \\
\text { and industrial zones } \\
\text { "B\&C" }\end{array}$ & 19 & $\begin{array}{l}13.31 \pm 3.59 \\
(3.74-17.07)\end{array}$ & $\begin{array}{c}6.49 \pm 0.23 \\
(3.12- \\
11.41)\end{array}$ & $\begin{array}{c}6.52 \pm 0.55 \\
(3.41- \\
12.65)\end{array}$ & $\begin{array}{c}96.21 \pm 1.60 \\
(60.33- \\
177.91)\end{array}$ \\
\hline Foundations & $\begin{array}{l}\text { 6th,7th,9th } \\
\text { settlements and the } \\
\text { entertainment area }\end{array}$ & 21 & $\begin{array}{l}12.96 \pm 3.63 \\
(9.92-16.69)\end{array}$ & $\begin{array}{l}3.71 \pm 0.16 \\
(2.33-7.62)\end{array}$ & $\begin{array}{l}4.03 \pm 0.46 \\
(2.38-5.70)\end{array}$ & $\begin{array}{c}78.12 \pm 1.46 \\
(49.93- \\
109.02)\end{array}$ \\
\hline Sand dunes & $\begin{array}{l}\text { Northern, western } \\
\text { extensions and golf } \\
\text { and Giro land area }\end{array}$ & 25 & $\begin{array}{l}13.36 \pm 4.32 \\
(9.99-18.69)\end{array}$ & $\begin{array}{l}3.87 \pm 0.17 \\
(2.09-8.24)\end{array}$ & $\begin{array}{l}3.90 \pm 0.45 \\
(2.51-6.88)\end{array}$ & $\begin{array}{c}76.27 \pm 1.43 \\
(52.89- \\
106.33)\end{array}$ \\
\hline rock & $\begin{array}{l}\text { 4th and 5th } \\
\text { settlement }\end{array}$ & 17 & $\begin{array}{l}26.74 \pm 5.50 \\
(4.34-66.59)\end{array}$ & $\begin{array}{c}19.38 \pm 0.64 \\
(9.00- \\
37.66)\end{array}$ & $\begin{array}{c}25.91 \pm 1.89 \\
(5.08- \\
48.94)\end{array}$ & $\begin{array}{c}215.71 \pm 3.35 \\
(56.17- \\
322.72)\end{array}$ \\
\hline
\end{tabular}

Table1.: The specific activity concentrations for $238 \mathrm{U}, 226 \mathrm{Ra}$ series, $232 \mathrm{Th}$ series and $40 \mathrm{~K}(\mathrm{~Bq} / \mathrm{kg})$ in Al-Obour city. 
The specific activities of $238 \mathrm{U}, 226 \mathrm{Ra}$ series, $232 \mathrm{Th}$ and $40 \mathrm{~K}$ in soil; foundations; sand dunes and rock samples have a mean of $(13.31 \pm 3.59) ;(12.96 \pm 3.63) ;(13.36 \pm 4.32)$ and $(26.74 \pm 5.50),(6.49 \pm 0.23) ;(3.71 \pm 0.16) ;(3.87 \pm 0.17)$ and (19.38 \pm 0.64$),(6.52 \pm 0.55) ;(4.03 \pm 0.46) ;(3.90 \pm 0.45)$ and $(25.91 \pm 1.89)$ and $(96.21 \pm 1.60) ;(78.12 \pm 1.46)$; $(76.27 \pm 1.43)$ and $(215.71 \pm 3.35) \mathrm{Bq} / \mathrm{kg}$, respectively. According to UNSCEAR 2000, the worldwide average concentrations for $238 \mathrm{U}, 232 \mathrm{Th}$ and $40 \mathrm{~K}$ are 35,30 and $400 \mathrm{Bqkg}-1$, respectively, which reveals that the activity of $238 \mathrm{U}, 232 \mathrm{Th}$ and $40 \mathrm{~K}$ measured for soil, foundations and sand dunes samples in the area under study are much lower than the world wide values. In the rock samples, the specific activity concentrations for $238 \mathrm{U}$ is much higher than the recommended limits in 6 samples and for 232Th is also high in 9 samples, while the activity concentrations for $40 \mathrm{~K}$ are low comparing to the recommended limits. The high values of $238 \mathrm{U}$ and 232Th radioactivity is noticed to be in the claystone rocks. Clay minerals are mainly composed of plate-like secondary aluminum silicate with small particle size and have a negatively charged surface. Therefore, clay particles have the ability to adsorb cations on their surface [18].The distribution of specific activities of $238 \mathrm{U}$, 226Ra series, 232Th and 40K is also described using SPSS statistical computer program for the samples as shown in Table2.and Fig.2(a, b, $c$ and d).

Table 2.: The activity concentrations distribution of 238U, 226Ra series, 232Th series and 40K in samples of AlObour city (in $\mathrm{Bq} / \mathrm{kg}$ ).

\begin{tabular}{lllll}
\hline & 238U & 226Ra & 232Th & 40K \\
\hline Mean & 16.02 & 7.65 & 9.10 & 110.27 \\
S.D & 10.43 & 7.56 & 11.31 & 72.79 \\
Skewness & 2.84 & 2.28 & 2.41 & 1.97 \\
Kurtosis & 8.93 & 5.01 & 4.75 & 2.69 \\
Range & $3.74-66.59$ & $1.90-37.66$ & $2.38-48.94$ & $47.99-326.61$ \\
$\begin{array}{l}\text { Frequency- } \\
\text { distribution }\end{array}$ & Log-normal & Log-normal & Log-normal & Log-normal \\
\hline
\end{tabular}

The table gives the statistics of the values corresponding to their activity values corresponding as measured for $238 \mathrm{U}, 226 \mathrm{Ra}, 232 \mathrm{Th}$ and $40 \mathrm{~K}$ in 82 samples of the area under study. It lists the respective mean value, range, skweness, kurtosis coefficients and the type of theoretical frequency distribution that best fits each empirical distribution [19]. 

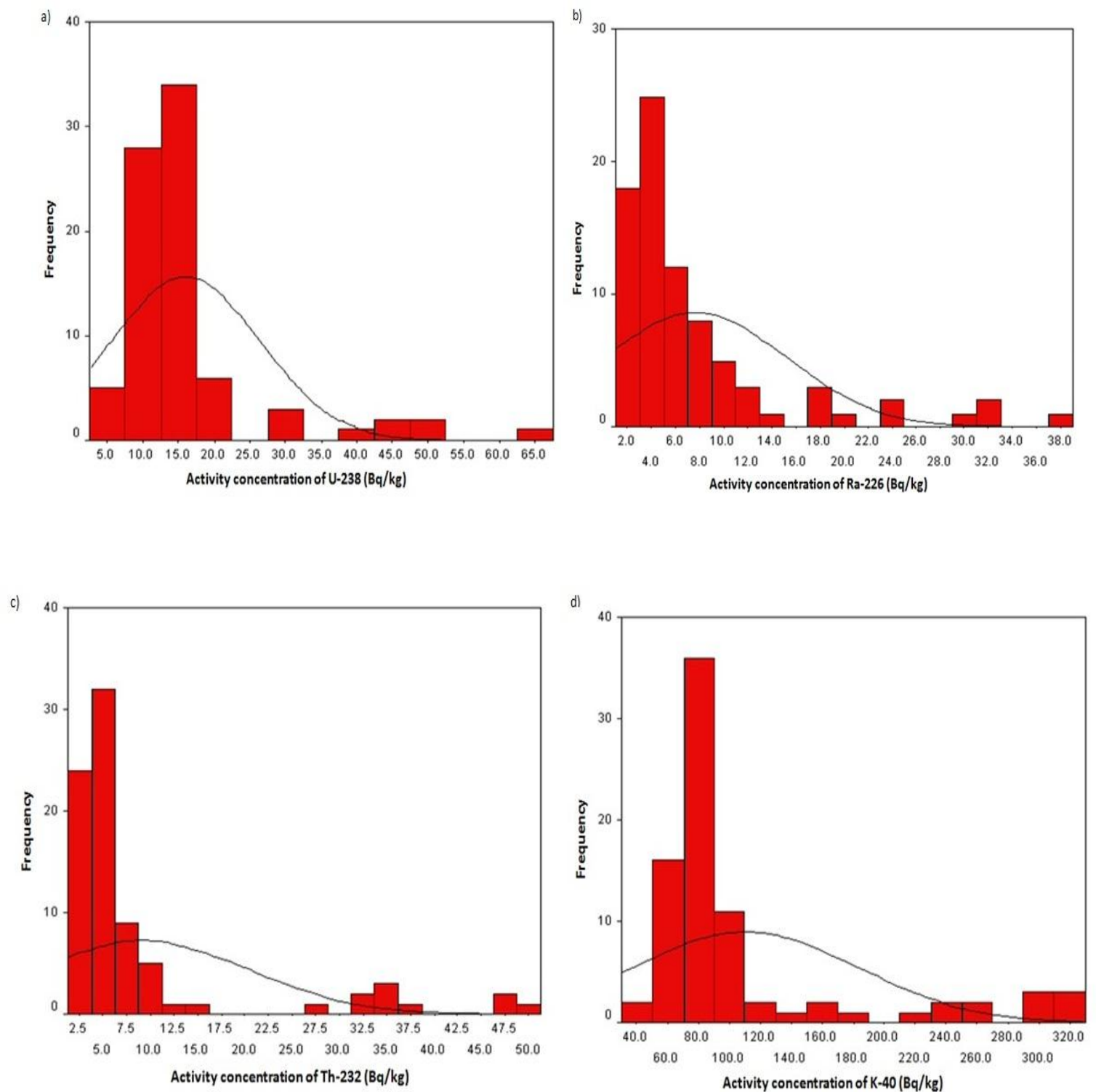

Fig.2: The activity concentrations distribution of 238U, 226Ra series, 232Th series and 40K in samples of AlObour city (in Bq/kg).

Skewness coefficient is a measure of the asymmetry of the probability distribution of a real-valued random variable. It can be positive or negative, or even undefined. Qualitatively, a negative skew indicates that the tail on the left side of the probability density function is longer than the right side and the bulk of the values lie to the left of the mean. A zero value indicates that the values are relatively evenly distributed on both sides of the mean, typically but not necessarily implying a symmetric distribution [20]. Kurtosis coefficient is any measure of the "peakedness" of the probability distribution of the real valued random variable. It is a descriptor of the shape of a probability [21]. It can be noticed from Fig. 2 that 238U, 226Ra, 232Th and 40K fitted a log-normal distribution as the positive values of kurtosis coefficient for them indicate that their distributions are higher and narrower than normal. 
Table 3: The Pearson correlation between radionuclide isotopes and heavy metals measured in soil samples of the understudy area.

\begin{tabular}{|c|c|c|c|c|c|c|c|c|c|c|}
\hline Variables & Cd & Co & $\mathrm{Cr}$ & $\mathrm{Cu}$ & $\mathrm{Fe}$ & Mn & $238 U$ & 226Ra & 232Th & $40 K$ \\
\hline Cd & 1.00 & & & & & & & & & \\
\hline Co & -0.15 & 1.00 & & & & & & & & \\
\hline $\mathrm{Cr}$ & -0.09 & $0.96^{*}$ & 1.00 & & & & & & & \\
\hline $\mathrm{Cu}$ & -0.02 & 0.58 & $0.64^{*}$ & 1.00 & & & & & & \\
\hline $\mathrm{Fe}$ & -0.18 & $0.97^{*}$ & $0.93^{*}$ & 0.56 & 1.00 & & & & & \\
\hline Mn & -0.04 & $0.78^{*}$ & $0.77^{*}$ & 0.43 & $0.88^{*}$ & 1.00 & & & & \\
\hline $238 \mathrm{U}$ & 0.34 & 0.40 & 0.38 & 0.13 & 0.34 & 0.31 & 1.00 & & & \\
\hline 226Ra & 0.05 & 0.55 & 0.57 & 0.18 & 0.59 & $0.70^{*}$ & 0.47 & 1.00 & & \\
\hline 232Th & -0.14 & $0.75^{\star}$ & $0.71^{*}$ & 0.22 & $0.77^{*}$ & $0.73^{*}$ & 0.50 & $0.87^{*}$ & 1.00 & \\
\hline $40 K$ & -0.29 & $0.65^{\star}$ & $0.61^{*}$ & 0.12 & $0.62^{*}$ & 0.49 & 0.34 & $0.61^{*}$ & $0.84^{*}$ & 1.00 \\
\hline
\end{tabular}

*. Correlation is significant at 0.05 level.

Table 3: Continued.

\begin{tabular}{|c|c|c|c|c|c|c|c|c|c|}
\hline Variables & $\mathbf{N i}$ & $\mathbf{P b}$ & Stronium & Vanadium & $\mathrm{Zn}$ & $238 U$ & 226Ra & $232 \mathrm{Th}$ & $40 \mathrm{~K}$ \\
\hline $\mathbf{N i}$ & 1.00 & & & & & & & & \\
\hline $\mathbf{P b}$ & 0.23 & 1.00 & & & & & & & \\
\hline Stronium & 0.44 & 0.46 & 1.00 & & & & & & \\
\hline Vanadium & 0.75 & 0.14 & 0.36 & 1.00 & & & & & \\
\hline Zn & 0.01 & 0.03 & -0.02 & -0.05 & 1.00 & & & & \\
\hline $238 U$ & 0.29 & 0.34 & 0.41 & 0.44 & -0.08 & 1.00 & & & \\
\hline 226Ra & 0.41 & 0.13 & 0.29 & $0.80^{*}$ & 0.05 & 0.47 & 1.00 & & \\
\hline 232Th & 0.62 & 0.16 & 0.24 & $0.87^{*}$ & 0.12 & 0.50 & $0.87^{*}$ & 1.00 & \\
\hline $40 K$ & 0.57 & 0.13 & 0.16 & 0.62 & 0.02 & 0.34 & $0.61^{*}$ & $0.84^{*}$ & 1.00 \\
\hline
\end{tabular}

*. Correlation is significant at 0.05 level.

Table3 shows the correlations between radioactive isotopes and heavy metals measured in 19 soil samples collected from the industrial areas in Al-Obour city. It has been noticed that there are a very good correlations between 226Ra, 232Th and 40K with Fe and Mn. Radium has been shown to absorb strongly to Fe(III) oxyhydroxides and $\mathrm{MnO} 2$ impregnated filtration has been used to extract both radium and thorium isotopes [22]. Also a good correlation between 232Th and 40K with Co and Cr. 226Ra and 232Th has a good correlation with Vanadium. From all of that we can see that $238 \mathrm{U}$ has week correlation with heavy metals while 226Ra, 
232Th and 40K have nearly the same behavior and good correlation with some of these heavy metals. These correlations are existed mainly due to the clay minerals in soil samples. Generally, clay minerals are mainly composed of plate-like secondary aluminum silicate with small particle size and have a negatively charged surface. Therefore, clay particles have the ability to absorb the cations on their surface and raise the level of radionuclide and heavy metal concentrations [23].

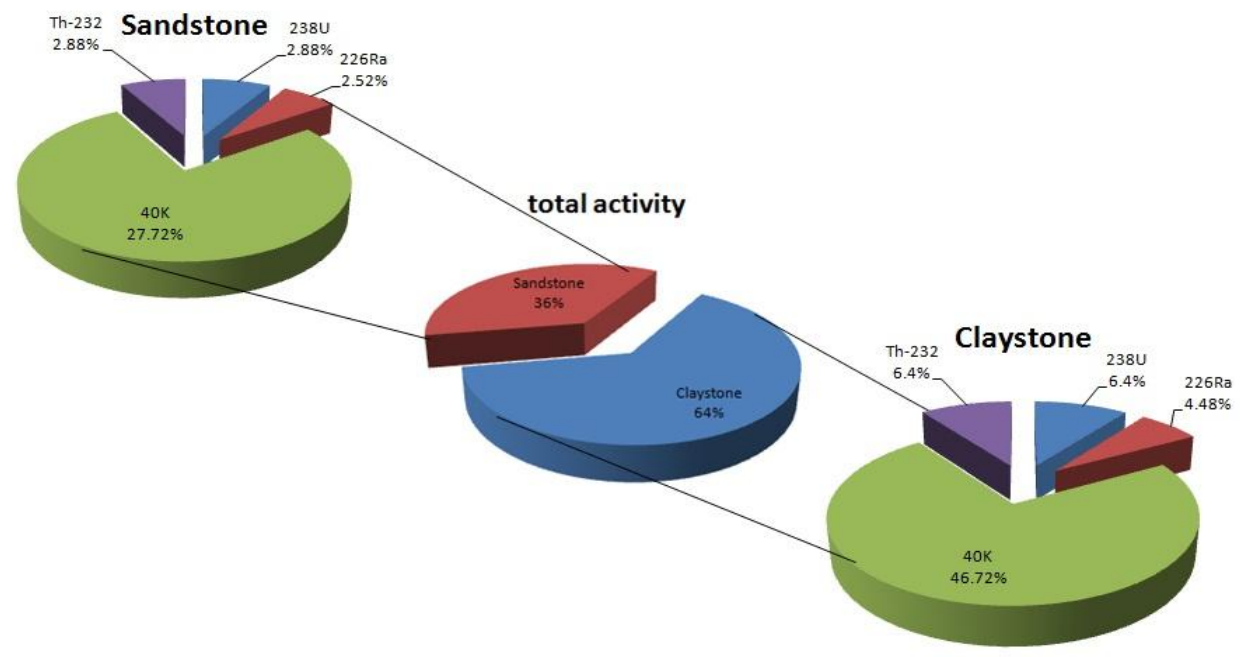

Fig.3: The distribution of natural radioactivity in the rock samples of Al-Obour city.

Fig. 3 shows the distribution of natural radioactivity in the rocks samples of Al-Obour city. It has been seen that most the activity is concentrated in the claystone rocks (64\%) and most the radioactivity in the rocks is coming from $40 \mathrm{~K}(73 \%)$ in claystone rocks and $(77 \%)$ in sandstone rocks.

Table 4.shows the ratios between the different isotopes in $238 \mathrm{U}$ series and 232Th series for each type of samples collected from the area under study. It can be noticed that for soil, foundations and sand dunes samples, the activity ratio of $238 \mathrm{U} / 226 \mathrm{Ra}$ is greater than 1 with averages of $2.03,3.51$ and 3.50 and ranges from 0.94 to $4.03,1.75$ to 5.98 and 1.51 to 6.74 , respectively, which indicates that there is a state of disequilibrium between the two radionuclides in the $\mathrm{U}$-series. This is explained by the difference in geochemical properties between the two radionuclides. Uranium has greater mobility than radium in the environment and $238 \mathrm{U}$ is rapidly transferred to deeper soil where it accumulates [10].On the other hand, The activity ratios of $238 \mathrm{U} / 226$ Rain rock samples range from 0.31 to 1.76 with average of 1.22 which is close to unity indicating a state of equilibrium in the samples. It also noticed that the ratios $226 \mathrm{Ra} / 214 \mathrm{~Pb}$ and $214 \mathrm{~Pb} / 214 \mathrm{Bi}$ have averages of 1.12 and $0.98,1.18$ and $0.96,1.15$ and 0.97 and 1.05 and 1.01 for soil, foundations, sand dunes and rock samples, respectively. It is obvious that the values are close to unity which shows a state of secular equilibrium within the $226 \mathrm{Ra}$ series. The ratio $228 \mathrm{Ac} / 212 \mathrm{Bi}$ and $212 \mathrm{Bi} / 208 \mathrm{TI}$ in the 232Th series have the averages of 1.00 and 1.08, 1.05 and 1.04, 1.04 and 0.99 and 1.00 and 1.02 for soil, foundations, sand dunes and rock samples, respectively. The values are close to unity which also indicates a state of secular equilibrium in the 232 Th series. 
Table 4.: The ratios of $238 \mathrm{U}$ and232Th series in samples collected from the area under study.

\begin{tabular}{|c|c|c|c|c|c|c|}
\hline \multirow{2}{*}{ Sample no. } & & \multicolumn{3}{|c|}{ 238U-series } & \multicolumn{2}{c|}{ 232Th-series } \\
\cline { 3 - 7 } & & 238U/226Ra & 226Ra/214Pb & 214Pb/214Bi & 228Ac/212Bi & 212Bi/208TI \\
\hline \multirow{2}{*}{ Soil } & Average & 2.03 & 1.12 & 0.98 & 1.00 & 1.08 \\
& Range & $(0.94-4.03)$ & $(0.99-1.29)$ & $(0.95-1.08)$ & $(0.86-1.15)$ & $(0.79-1.57)$ \\
\hline \multirow{2}{*}{ Foundations } & Average & 3.51 & 1.18 & 0.96 & 1.05 & 1.04 \\
& Range & $(1.75-5.98)$ & $(0.85-1.62)$ & $(0.88-1.98)$ & $(0.89-1.54)$ & $(0.58-1.36)$ \\
\hline \multirow{2}{*}{ Sand dunes } & Average & 3.50 & 1.15 & 0.97 & 1.04 & 0.99 \\
& Range & $(1.51-6.74)$ & $(0.87-1.45)$ & $(0.92-1.05)$ & $(0.80-1.36)$ & $(0.85-1.23)$ \\
\hline \multirow{2}{*}{ Rock } & Average & 1.22 & 1.05 & 1.01 & 1.00 & 1.02 \\
& Range & $(0.31-1.76)$ & $(0.98-1.19)$ & $(0.97-1.05)$ & $(0.90-1.03)$ & $(0.90-1.14)$ \\
\hline
\end{tabular}

The distribution of 238U, 226Ra, 232Th and 40K in the whole city of Al-Obour is as shown in Fig.4(a, b, c and d) using Surfer 9. computer program. It shows that $238 \mathrm{U}$ is concentrated in northwest of the city, while 226Ra, 232Th and40K have nearly the same distribution and concentrated in the middle of the city. Hence, Ra and Th are low solubility in soil. It was concluded that radium does not migrate through the soil, except for dispersed or dissolved 226Ra. Even then, adsorption in the soil solid phase leads to a very low average migration [24]. Uranium is mobile under oxidizing conditions whereas radium and thorium are essentially immobile in the surficial environment, the differing mobility's of these radionuclides has previously been identified as causing disequilibrium in young organic uranium deposits [25]. This explains difference in behavior and distribution of uranium comparing with radium and thorium.

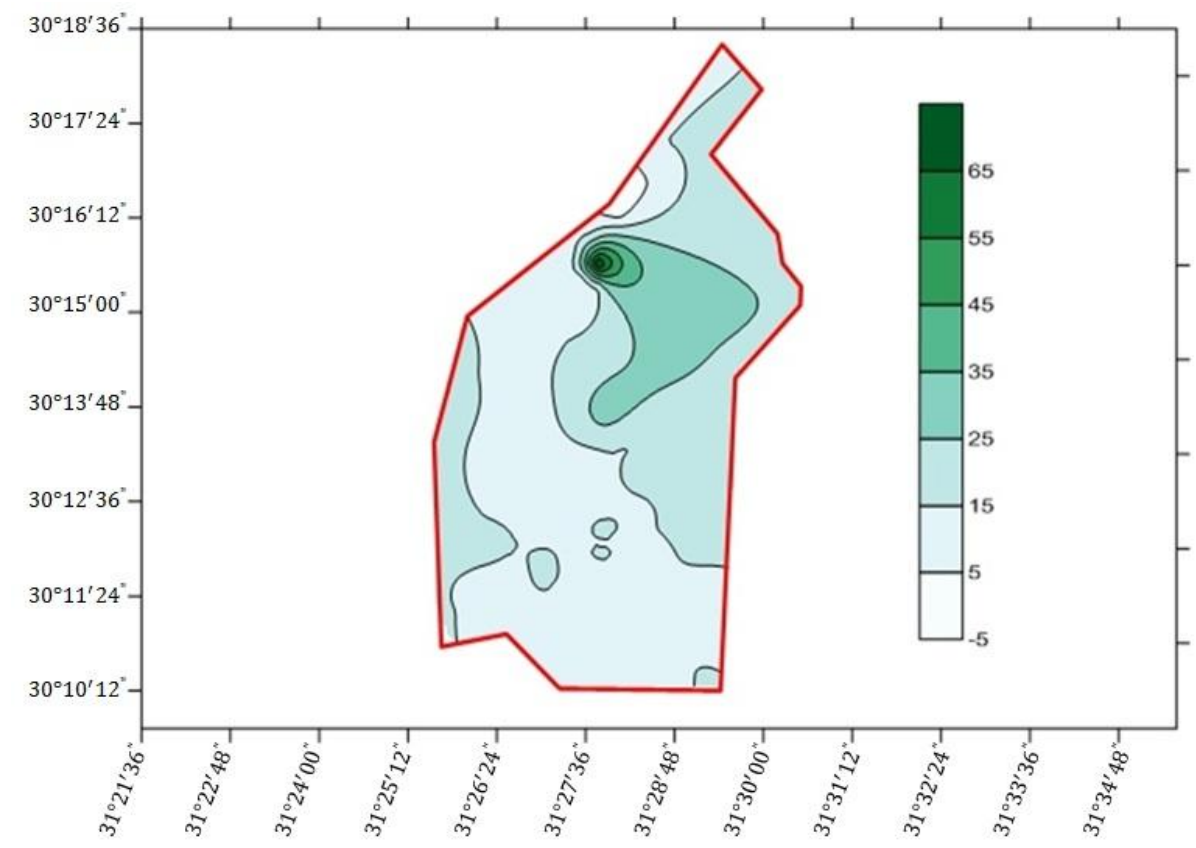

Fig.(4-a): The distribution of $238 \mathrm{U}$ in Al-Obour city. 


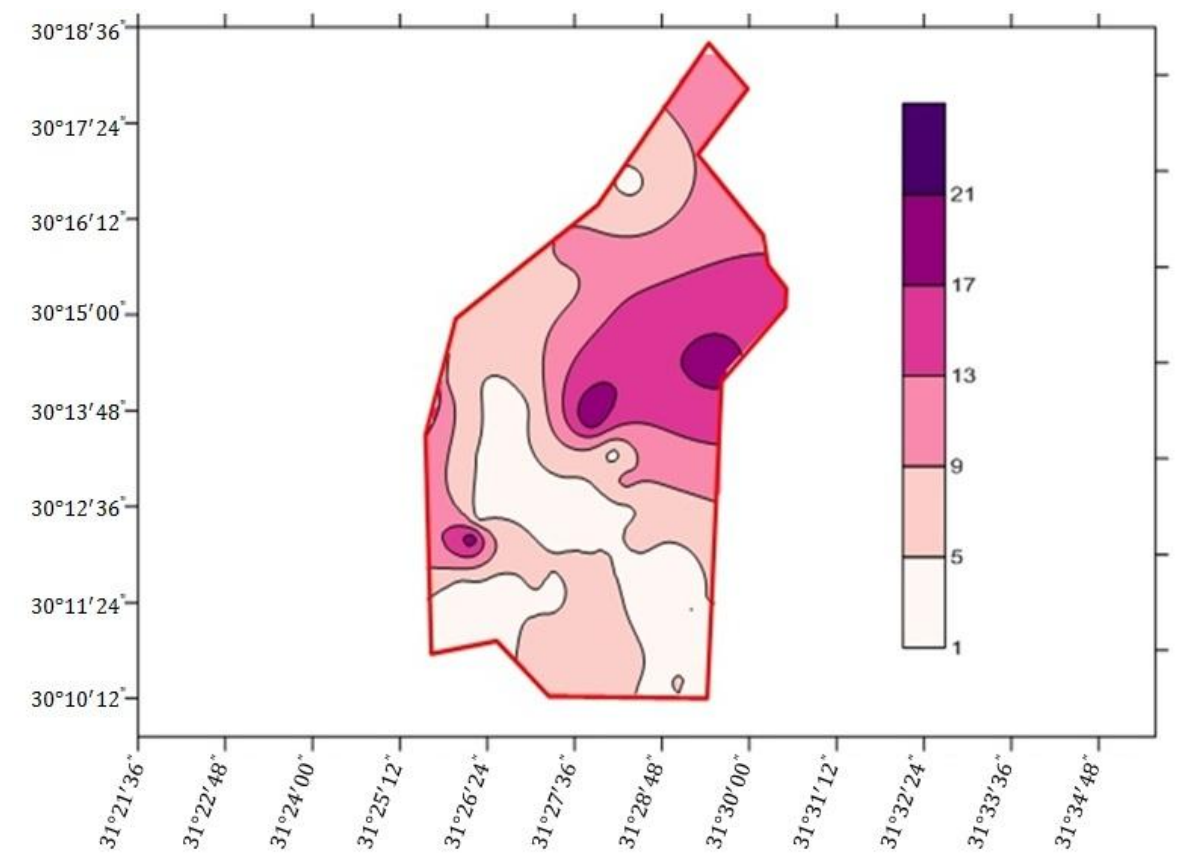

Fig.(4-b): The distribution of 226Ra in Al-Obour city.

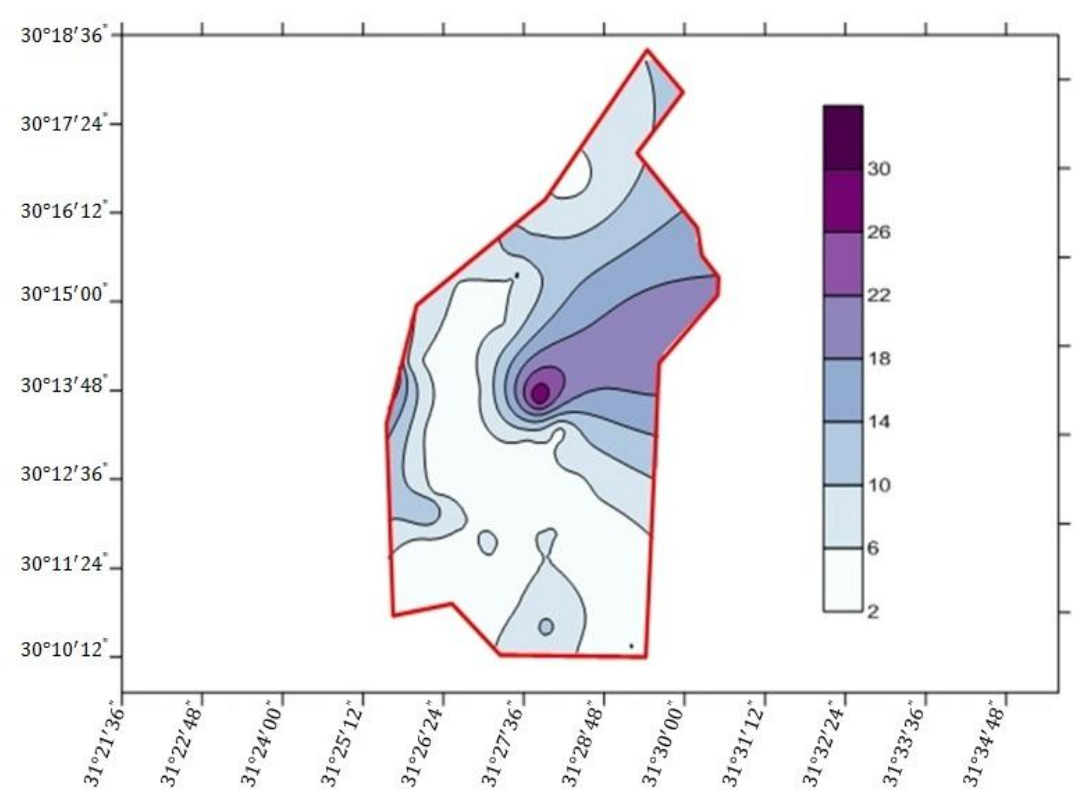

Fig.(4-c): The distribution of 232Th in Al-Obour city. 


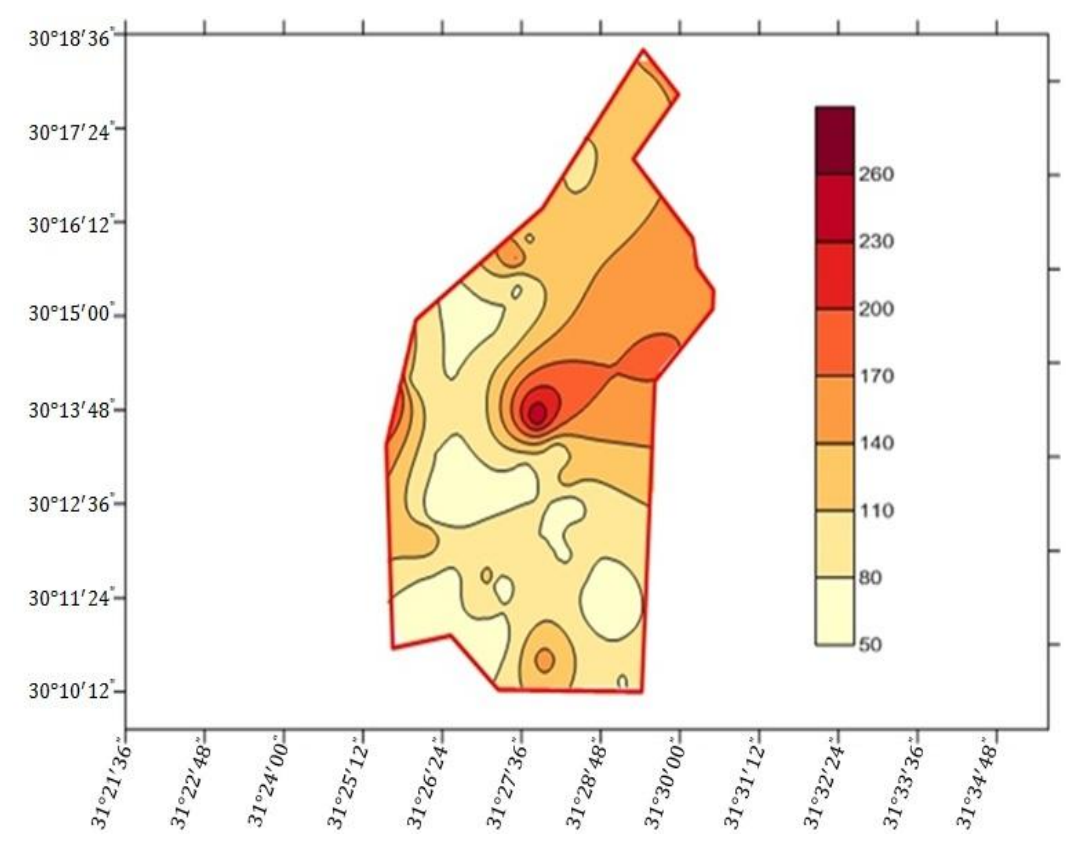

Fig.(4-d): The distribution of 40K in Al-Obour city.

It is very important to estimate the hazard indices of the samples to be sure about the safety of the area under study and see if there are percussions needed while working or living in or around the area under study. The hazard indices in soil samples of Al-Obour city is shown in Table 5.

Table 5: The range and average of dose rate, the annual effective dose(AED), radium equivalent and external index.

\begin{tabular}{|c|c|c|c|c|c|c|c|c|}
\hline \multirow{2}{*}{$\begin{array}{c}\text { Hazard } \\
\text { indices }\end{array}$} & \multicolumn{2}{|c|}{ soil } & \multicolumn{2}{c|}{ foundations } & \multicolumn{2}{c|}{ Sand dunes } & \multicolumn{2}{c|}{ rock } \\
\cline { 2 - 10 } & range & average & range & average & range & average & range & Average \\
\hline D(nGy/h) & $\begin{array}{c}9.16- \\
23.08\end{array}$ & 14.14 & $\begin{array}{c}9.42- \\
15.27\end{array}$ & 11.56 & $\begin{array}{c}9.66- \\
15.70\end{array}$ & 11.57 & $\begin{array}{l}8.05- \\
71.62\end{array}$ & 37.85 \\
\hline AED(mSv/y) & $0.01-0.03$ & 0.02 & $0.01-0.02$ & 0.01 & $\begin{array}{c}0.01- \\
0.02\end{array}$ & 0.01 & $0.01-0.09$ & 0.05 \\
\hline Raeq(Bq/kg) & $13.04-$ & 23.23 & $\begin{array}{c}9.93- \\
24.82\end{array}$ & 15.48 & $\begin{array}{l}9.77- \\
26.27\end{array}$ & 15.32 & $\begin{array}{c}20.59- \\
126.95\end{array}$ & 73.04 \\
\hline Hex & $0.04-0.11$ & 0.06 & $0.03-0.07$ & 0.04 & $\begin{array}{c}0.03- \\
0.07\end{array}$ & 0.04 & $0.06-0.34$ & 0.20 \\
\hline
\end{tabular}

The dose rate was found to be $14.14,11.56,11.57$ and $37.85 \mathrm{nGy} / \mathrm{h}$ with ranges of 9.16 to $23.08,9.42$ to 15.27 , 9.66 to 15.70 and 8.05 to $71.62 \mathrm{nGy} / \mathrm{h}$ for soil, foundations, sand dunes and rock samples, respectively. All the samples collected from Al-Obour city were found to be within the recommended limits except for 2 claystone rock samples which have higher dose rates. The annual effective dose (AED), Raeq and Hex were noticed to be within the limits recommended by UNSCEAR,2000. Fig. 5 shows the dose rate distribution in the samples collected from the area under study comparing with the worldwide. 


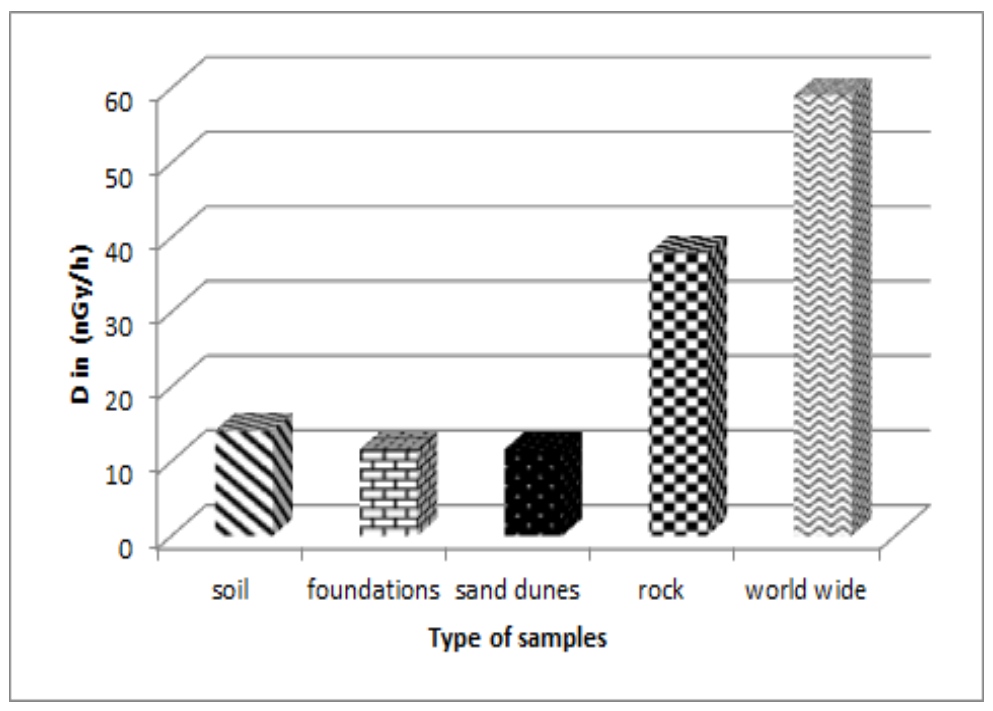

Fig.5: The dose rate distribution in Al-Obour city.

Table 6: The calculated AGED, AUI and ELCR for all samples

\begin{tabular}{|c|c|c|c|c|c|}
\hline Type & Location & $\begin{array}{c}\text { No. of } \\
\text { samples }\end{array}$ & AGED & AUI & ELCR \\
\hline Soil & $\begin{array}{c}\text { First } \\
\text { industrial area } \\
\text { and industrial } \\
\text { zones "B\&C" }\end{array}$ & 19 & $0.077 \pm .003$. & $0.15 \pm 0.009$ & 0.049 \\
\hline Foundations & $\begin{array}{c}\text { 6th,7th,9th } \\
\text { settlements } \\
\text { and the } \\
\text { entertainment } \\
\text { area }\end{array}$ & 21 & $0.052 \pm 0.002$ & $0.09 \pm 0.007$ & 0.040 \\
\hline Sand dunes & $\begin{array}{c}\text { Northern, } \\
\text { western } \\
\text { extensions } \\
\text { and golf and } \\
\text { Giro land area }\end{array}$ & 25 & $0.052 \pm 0.002$ & $0.09 \pm 0.007$ & 0.040 \\
\hline rock & $\begin{array}{c}\text { 4th and 5th } \\
\text { settlement }\end{array}$ & 17 & $0.235 \pm 0.011$ & $0.52 \pm 0.031$ & 0.132 \\
\hline
\end{tabular}

It is important to assess the annual gonadal dose equivalent (AGDE), activity utilization index (AUI) and excess lifetime cancer risk (ELCR). These parameters are indicate the human risk due to the natural radiation emitted to the sensitive organs. The permissible values of these ELCR parameters should be less than the unity, but the results in table (6) show that the values are less than unity this leads to safety region for peoples stayed. 


\section{Conclusions}

The results of this study will provide background data on natural and artificial radioactive isotopes and environmental pollution. The distribution of natural radioactivity was determined and showed that the radioactivity in all types of samples was very low except for the rock. The claystone samples in rock showed much higher radioactivity for $238 \mathrm{U}$ and 232Th.137Cs is existed in some samples but is close to the background level. The hazards were determined for all samples and the area is considered to be safe for human activities.

\section{References}

1. Arnedo, M.A. , Rubiano, J.G. , Alonso, H. , Tejera, A.,Gonz_alez, A., Gonz_alez, J., Gil, J.M., Rodríguez, R., Martel, P., Bolivar, J.P., (2017): "Mapping natural radioactivity of soils in the eastern Canary Islands". Journal of Environmental Radioactivity, V. 166, pp. 242-258.

2. Agbalagba, E.O. and Onoja, R.A. ,(2011): "Evaluation of natural radioactivity in soil, sediment and water samples of Niger Delta (Biseni) flood plain lakes, Nigeria". J. Environment Radioactivity, V.102, pp. 667-671.

3. Abdel-Ghany, H.A. , El-Zakla, T. and Hassan, A.M. ,(2009): "Environmental radioactivity measurements of some egyption sand samples". Rom. Journ. Phys., V.54, pp.213-223.

4. Kotb, A. , De Smedt, F. , Hassan, A. , and Taha, M. ,(2009): "Use of geophysical techniques to study water logging in EL Obour city, Egypt". Third international conference Geologica Belgica 2009, Ghent University, pp. 35

5. Hashem, W. ,(1997): "Engineering geology of El Obour City East of Cairo, Egypt". M.Sc. Thesis, Faculty of Science, Ain Shams Univ.

6. Abbady, E.G.A., Uosif, M. A. M. , El-Taher, A. ,(2005): "Natural radioactivity and dose assessment for phosphate rocks from wadi El-Mashash and El-Mahamid Mines, Egypt". J. Environ. Radiat., V.84, pp.65-78.

7. IAEA ,(1987):"'Preparation and certification of IAEA gamma spectrometry reference materials, RGU-1, RGTh-1 and RGK-1". Report IAEA/RL/148. International Atomic Energy Agency.

8. Anjos, R. M. , Veiga, R., Soares, T. , Santos, A. M. A. , Aguiar, J. G. , Frasca', M. H. B. O. , Brage, J. A. P. , Uze^da, D. , Mangia, L. , Facure, A. , Mosquera, B. , Carvalho, C., Gomes, P. R. S. ,(2005):"Natural radionuclide distribution in Brazilian commercial granites". J. Radiat. Meas., V.39, pp.245-253.

9. Stoulos, S. , Manolopoulou, M. , Papastefanou, C. ,(2003):"Assessment of natural radiation exposure and radon exhalation from building materials in Greece". J. Environ. Radioact.,V.69, pp.225-240.

10. Nada, A. , Abd-ElMaksoud, T. M. , Abu-Zeid, H. M. , El-Nagar, T. and Awad, S. , (2009): "Distribution of radionuclides in soil samples from a petrified wood forest in El-Qattamia, Cairo, Egypt". J. Applied Radiation and Isotopes, V. 67, pp. 643-649.

11. Jibiri, N. N. , Farai, P. I. , Alausa, K. S. ,(2007): "Estimation of annual effective dose due to natural radioactive elements in ingestion of foodstuffs in tin mining area of Jos-Plateau, Nigeria". J. Environ. Radiat, V.94, pp. 31-40.

12. UNSCEAR, (2000): "Sources and Effects of Ionizing Radiation". United Nations Scientific Committee on the Effect of Atomic Radiation, Report to the General Assembly annexes, United Nations, New York. USA. 
13. Jibiri, N. N., Bankole, S.O. ,(2006): "Soil radioactivity and radiation absorbed dose rates at roadsides in high-traffic density areas in Ibadan Metropolis, southwestern Nigeria". Radiat. Prot. Dosimetry, V. 118, pp. $453-458$.

14. OECD, Organization for Economic Cooperation and Development, (1979): "Exposure to Radiation from Natural Radioactivity in Building Materials". Report by a Group of Experts of the OECD Nuclear Energy Agency, OECD, Paris.

15. Huy, N. Q. , and Luyen, T. V. (2006): "Study on external exposure doses from terrestrial radioactivity in southern Vietnam". Radiat. Prot. Dosimetry,V.118, pp.331-336.

16. Matthew, T.K., Abdul Aziz, S.A.B., Khandaker, M.U., Asaduzzaman, K., Amin, Y.M., (2015): "Evaluation of radiological risks due to natural radioactivity around Lynas AdvancedMaterial Plant environment, Kuantan, Pahang, Malaysia". Environ. Sci. Pollut. Res., V. 22, pp.13127-13136.

17. Hilal, M.A, Borai, E.H., (2018): "Hazardous parameters associated with natural radioactivity exposure from black sand". Journal of Regulatory Toxicology and Pharmacology, V. 92, pp. 245-250.

18. EL-Arabi, A. M. , Abbady, A. G. E. and Hussein, A. S. ,(2006): "Gamma-ray measurements of natural radioactivity in sedimentary rocks from Egypt". Nuclear Science and Techniques, V. 17, pp. 123-128.

19. Selvasekarapandian, S., Sivakumar, R. , Manikandan, N. M. ,Meenakshisundaram, V., Raghunath, V. M. , Gajendran, V. ,(2000): "Natural radionuclide distribution in soils of Gudalore, India". J. Applied radiation and isotopes, V.52, pp.299-306.

20. http://en.wikipedia.org/wiki/Skewness.

21. http://en.wikipedia.org/wiki/Kurtosis.

22. Yeager, K. M. and Santschi, P. H. ,(2003): "Invariance of isotope ratios of lithogenic radionuclides: more evidence for their use as sediment source tracers". J. Environmental Radioactivity, V. 69, pp. 159-176.

23. Sursh, G. , Ramasamy, V., Meenakshisundaram, V. , Venkatachalapathy, R. , Ponnusamy, V. ,(2011): "Influence of mineralogical and heavy metal composition on natural radionuclide concentrations in river sediments". J. Applied radiation and isotopes, V.69, pp.1466-1474.

24. Boscov, M. E.G, Cunh, I. I. L. and Saito, R. T. ,(2001): "Radium migration through clay liners at waste disposal sites". The Science of the Total Environment, V. 266, pp. 259-264.

25. Dowdall, M. , and O'Dea, J. ,(2004): "226Ra/238U disequilibrium in an upland organic soil exhibiting elevated natural radioactivity". J. Environmental Radioactivity, V. 59, pp. 91-104. 